\title{
Bioconservation of Historic Stone Buildings-An Updated Review
}

\author{
Benjamín Otto Ortega-Morales ${ }^{1}$ and Christine Claire Gaylarde ${ }^{2, *}$ \\ 1 Department of Environmental Microbiology and Biotechnology, Universidad Autónoma de Campeche, \\ Av. Agustín Melgar s/n. C.P., 24039 Campeche, Mexico; beortega@uacam.mx \\ 2 Department of Microbiology and Plant Biology, Oklahoma University, 770 Van Vleet Oval, \\ Norman, OK 73019, USA \\ * Correspondence: cgaylarde@gmail.com
}

check for updates

Citation: Ortega-Morales, B.O.; Gaylarde, C.C. Bioconservation of Historic Stone Buildings-An Updated Review. Appl. Sci. 2021, 11, 5695. https://doi.org/10.3390/ app11125695

Academic Editors: Maria

Filomena Macedo, António Manuel Santos Carriço Portugal, Ana Miller and Ana Catarina Pinheiro

Received: 22 February 2021

Accepted: 16 June 2021

Published: 19 June 2021

Publisher's Note: MDPI stays neutral with regard to jurisdictional claims in published maps and institutional affiliations.

Copyright: (c) 2021 by the authors. Licensee MDPI, Basel, Switzerland. This article is an open access article distributed under the terms and conditions of the Creative Commons Attribution (CC BY) license (https:// creativecommons.org/licenses/by/ $4.0 /)$.

\begin{abstract}
Cultural heritage buildings of stone construction require careful restorative actions to maintain them as close to the original condition as possible. This includes consolidation and cleaning of the structure. Traditional consolidants may have poor performance due to structural drawbacks such as low adhesion, poor penetration and flexibility. The requirement for organic consolidants to be dissolved in volatile organic compounds may pose environmental and human health risks. Traditional conservation treatments can be replaced by more environmentally acceptable, biologicallybased, measures, including bioconsolidation using whole bacterial cells or cell biomolecules; the latter include plant or microbial biopolymers and bacterial cell walls. Biocleaning can employ microorganisms or their extracted enzymes to remove inorganic and organic surface deposits such as sulfate crusts, animal glues, biofilms and felt tip marker graffiti. This review seeks to provide updated information on the innovative bioconservation treatments that have been or are being developed.
\end{abstract}

Keywords: biocleaning; bioconsolidation; biocalcification; biopolymers; carbonatogenic bacteria; cultural heritage; MICP; microorganisms; stone restoration

\section{Introduction}

Our stone cultural heritage is subject to weathering over the years. This deterioration is due to physical, chemical and biological factors acting synergistically that cause disfiguration and dissolution of the stone, an increase in porosity and overall weakening of the structure [1]. When the building is of historic and cultural importance, it is necessary that careful restorative action be taken, with the aim of returning the monument, as much as possible, to its original condition. This may involve removal of unwanted surface deposits (cleaning) and strengthening of degraded parts of the structure (consolidation), and ultimately replacement of blocks or whole sections of the structure. Several processes, such as microbial transformation of stone minerals [1], discoloring by microbial pigments including algal, bacterial and fungal biomolecules with staining properties [2-5], and atmospheric pollutant deposition [6], which may all operate simultaneously at surfaces, can make cleaning procedures challenging. Furthermore, cleaning can induce irreversible damage; thus a cost-benefit analysis should be considered in a prior assessment phase, in order to reduce potential risks to artwork [7].

The consolidation and conservation of these buildings requires the use of materials that are compatible with the original structure. Consolidants that have been used in the past, or, indeed, are still in use, include those based on lime water, which is not very efficient [8], and silicic acid, which can lack the necessary flexibility for resisting stresses within the stone [9]. Nanoconsolidants, used as recent improvements in consolidation strategies [10] include the use of nanolime [11] and nanosilica and may be more effective in reducing porosity $[12,13]$. Nanolime doped with calcium hydroxide/zinc oxide quantum dots has been shown to form a more durable conservation treatment for limestone than silica-based consolidants [14], but it is more costly. The disadvantages of traditional consolidants, for 
both calcareous and siliceous stone, are poor performance, structural drawbacks such as low adhesion, poor penetration and flexibility and, in the case of organic substances such as alkoxysilanes, the necessity to be dissolved in volatile organic compounds (VOCs), which carry environmental and human health risks [15].

Synthetic resins, such as silane, epoxy, acrylic and polysiloxane, plug the pores when they polymerize, thus causing water retention and internal degradation, while external coatings can peel off. In order to increase the efficiency, several chemical modifications of old consolidants have been produced [16]. However, perhaps more promising are the new, biologically-based consolidants (bioconsolidants), which do not rely on synthetic components, but are naturally-occurring structural plant biopolymers [17,18], or utilize the enzyme activities of microorganisms to produce new materials.

Not only consolidants, but other traditional conservation treatments, can be replaced by more environmentally acceptable, biologically-based, measures to restore stone. This review seeks to provide updated information on these innovative conservation treatments that have been or are being developed.

\section{Bioconsolidation Techniques}

According to Wheeler [19], a consolidant is a material, or system of more than one material, that penetrates a substratum, improving the inner structure and thereby enhancing the mechanical properties, thus improving the adhesion of surfaces. A good consolidant needs to meet three criteria: (i) compatibility (not causing chemical or physical damage) with the original substratum; (ii) effectiveness by penetrating evenly within the inner structure, and (iii) durability by not yielding noxious by-products after application. Recently, Negri et al. [20] also stressed the need to meet the retractability criterion by not interfering with previous interventions.

Limestone and lime-based mortars have been consolidated using plant biopolymers. Reported biopolymers have been sourced from Aloe vera, Cylindropuntia californica, Opuntia engelmannii, Opuntia ficus-indica, Salvia hispanica and Sida angustifolia [17,21]. Biopolymers are obtained in a range of extraction procedures, soaking leaves and other leafy tissues in batches of water and subsequently leaving them to be released into the bulk water. This water containing the biopolymers is then used for mixing with lime and other materials and used for consolidation or used as a suspension. Consolidants are then applied to the stone surface using techniques such as spraying, brushing or partial immersion, or mixed with other materials to yield composites [22]. Biopolymers alter mechanical properties of building materials and their water absorption and diffusion behavior, thus increasing cohesion and enhancing mechanical properties [23]. Bioconsolidation is also achieved by direct or indirect application of microorganisms and/or their metabolites [24]. Microbially induced carbonate precipitation (MICP), also known as biocalcification, biocarbonatogenesis, or biomineralization, has been suggested as an environmentally friendly method for the consolidation of cultural heritage buildings. It is a natural phenomenon, induced by a wide variety of microorganisms, that can be responsible for chalking (the production of a white, powdery surface) [25], as well as playing an essential role in the formation of stromatolites [26]. This microbially mediated mineralization treatment must produce a coherent calcium carbonate layer that can protect deteriorated stone against water uptake and consolidate its inner structure. Such a natural process should result in a mineral product similar to the initial calcareous stone substrate, a highly desirable result in the eyes of conservators.

There have been several strategies: the application of selected carbonatogenic bacteria to the stone, enrichment of naturally occurring carbonatogenic bacteria, application of cell-free bacterial products, and stimulation of the relevant microorganisms among those already present (autochthonous microorganisms). There have been a number of reviews covering these options in recent years [26-31]. In this bibliographic search, we have attempted to avoid the sometimes lengthy discussions of the history behind the application of the technology and its variants, along with the minutiae of the treatments, preferring to 
reference such studies and using Table 1 to indicate relevant aspects of the developmental research. We have also considered the less frequently discussed environmental impacts of the new methods; only very recently have the effects on the normal microbial communities of the stone surfaces, and the resistance of the restoration to colonization by potential deteriogens been considered. A perspective on the development of biotechnological sustainable products for ultimate long-term use is also included.

\subsection{Microbial Cells in Bioconsolidation Treatments}

When considering the application of selected bacteria, a good option is to use organisms isolated from the autochthonous population, which are obviously already adapted to the stone environment and are less likely to interact negatively with the endogenous community $[24,32,33]$. The first such bacterial strain to be so isolated was a Bacillus cereus, which produced carbonate crystals in the alkaline conditions caused by breakdown of amino acids to ammonia [34]. It was successfully tested in the field in 1999 (see Table 1 [35]).

Table 1. Examples of carbonatogenic microorganisms that have been tested for MICP potential.

\begin{tabular}{|c|c|c|c|}
\hline Organisms & $\begin{array}{c}\text { Isolation Source/ } \\
\text { Habitat }\end{array}$ & Testing Method & Reference \\
\hline $\begin{array}{l}\text { Bacillus, Pseudomonas, } \\
\text { Brevibacterium, } \\
\text { Streptomyces, } \\
\text { Stenotrophomonas genera }\end{array}$ & $\begin{array}{l}\text { Degraded limestone } \\
\text { monument (Romania) } \\
\text { Isolated during the } \\
\text { course of the study }\end{array}$ & $\begin{array}{l}\text { Crystal formation by isolated strains } \\
\text { on solid medium; crystal } \\
\text { identification by FTIR, XRD and SEM }\end{array}$ & [36] \\
\hline Acinetobacter sp. & $\begin{array}{l}\text { Cave (Yixing Shanjuan, } \\
\text { China) } \\
\text { Carbonate stone (Spain) } \\
\text { Isolated during the } \\
\text { course of the study }\end{array}$ & $\begin{array}{l}\text { Consolidation of artificial cracks in } \\
\text { masonry cement mortars; } \\
\text { compressive strength, water } \\
\text { absorption, SEM, XRD, } \\
\text { thermogravimetry } \\
\text { In vitro consolidation with } \\
\text { Mixococcus xanthus; chemical analysis } \\
\text { of calcarenite stone }\end{array}$ & [37] \\
\hline $\begin{array}{l}\text { Agrococcus jejuensis sMM51 } \\
\text { (Soil, Middle Muschelkalk) }\end{array}$ & $\begin{array}{l}\text { Limestone-associated } \\
\text { groundwater, rock and } \\
\text { soil (Germany) }\end{array}$ & $\begin{array}{l}\text { Crystal formation in liquid culture; } \\
\text { crystal morphology by XRD, EDS } \\
\text { and SEM }\end{array}$ & [38] \\
\hline $\begin{array}{l}\text { Bacillus muralis rLMd } \\
\text { (Rock, Lower } \\
\text { Muschelkalk) } \\
\text { Bacillus sp. rMM9 (Rock, } \\
\text { Middle Muschelkalk) }\end{array}$ & $\begin{array}{l}\text { The strains are deposited } \\
\text { with the Jena Microbial } \\
\text { Resource Collection } \\
\text { (Jena, Germany) }\end{array}$ & & \\
\hline $\begin{array}{l}\text { Bacillus subtilis } 168 \\
\left({ }^{\circledR} 27370\right)\end{array}$ & $\begin{array}{l}\text { ATCC: American Type } \\
\text { Culture Collection, } \\
\text { Manassas (VA) USA }\end{array}$ & $\begin{array}{l}\text { Crystal formation on solid medium; } \\
\text { detailed crystal analysis }\end{array}$ & [39] \\
\hline $\begin{array}{l}\text { Indigenous bacterial } \\
\text { community }\end{array}$ & $\begin{array}{l}\text { Salt-damaged carbonate } \\
\text { stone in San Jeronimo } \\
\text { Monastery, Spain. } \\
\text { Isolated during the } \\
\text { course of the study }\end{array}$ & $\begin{array}{l}\text { Consolidation of originating } \\
\text { monument; drilling resistance, SEM }\end{array}$ & {$[24]$} \\
\hline $\begin{array}{l}\text { Synechococcus pevalleikii } \\
\text { (live and dead) }\end{array}$ & $\begin{array}{c}\text { National marine } \\
\text { laboratories, } \\
\text { Bharathidasan } \\
\text { University, } \\
\text { Tiruchirappalli, Tamil } \\
\text { Nadu, India }\end{array}$ & $\begin{array}{l}\text { Concrete cubes in vitro. U-V treated } \\
\text { cells gave better compressive } \\
\text { strength and lower water uptake }\end{array}$ & {$[40]$} \\
\hline Synechocystis (6803) & $\begin{array}{l}\text { PCC: Pasteur Culture } \\
\text { Collection (Paris), } \\
\text { France }\end{array}$ & $\begin{array}{l}\text { Morphological and spectroscopic } \\
\text { changes of mortar surfaces }\end{array}$ & {$[41]$} \\
\hline Gloeocapsa (73106). & $\begin{array}{l}\text { PCC: Pasteur Culture } \\
\text { Collection (Paris), } \\
\text { France }\end{array}$ & $\begin{array}{l}\text { Measurement of compressive } \\
\text { strength, water absorption and } \\
\text { porosity of treated mortar }\end{array}$ & {$[42]$} \\
\hline $\begin{array}{l}\text { Pseudomonas sp. (N9), } \\
\text { Bacillus cereus (T6), } \\
\text { Lysinibacillus sphaericus } \\
\text { (T5), Bacillus sp. }\end{array}$ & $\begin{array}{l}\text { Historic white marble } \\
\text { (China) } \\
\text { Isolated during the } \\
\text { course of the study }\end{array}$ & $\begin{array}{l}\text { Crystal formation in solid and liquid } \\
\text { culture by XRD analysis }\end{array}$ & [43] \\
\hline
\end{tabular}


Table 1. Cont.

\begin{tabular}{|c|c|c|c|}
\hline Organisms & $\begin{array}{c}\text { Isolation Source/ } \\
\text { Habitat }\end{array}$ & Testing Method & Reference \\
\hline Bacillus sp., Micrococcus sp. & $\begin{array}{l}\text { Black crusts on } \\
\text { limestone buildings } \\
\text { Isolated during the } \\
\text { course of the study }\end{array}$ & $\begin{array}{l}\text { Bio-cementation on limestone slabs; } \\
\text { Bio-consolidation of fragmented } \\
\text { stones (Church of Santa Maria dei } \\
\text { Miracoli, Venice); SEM, EDX }\end{array}$ & [44] \\
\hline Bacillus cereus & $\begin{array}{l}\text { Natural carbonate rock } \\
\text { Isolated during the } \\
\text { course of the study }\end{array}$ & $\begin{array}{l}\text { First in situ consolidation attempt } \\
\text { (Saint Médard Church, Thouars, } \\
\text { France); SEM, water absortion, } \\
\text { surface roughness, colorimetry }\end{array}$ & [45] \\
\hline Bacillus subtilis LMG 3589 & $\begin{array}{l}\text { Belgian Co-ordinated } \\
\text { Collections of } \\
\text { Microorganisms }\end{array}$ & $\begin{array}{l}\text { Consolidation of deteriorated } \\
\text { Globigerina limestone in Malta; } \\
\text { drilling resistance, water absorption, } \\
\text { salt deterioration, porosity }\end{array}$ & [46] \\
\hline $\begin{array}{c}\text { Lysinibacillus sphaericus, } \\
\text { Bacillus subtilis, } \\
\text { Pseudomonas putida }\end{array}$ & $\begin{array}{l}\text { INQCSS: Instituto } \\
\text { Nacional de Controle de } \\
\text { Qualidade em Saúde. } \\
\text { Brazilian Culture } \\
\text { Collection (Rio de } \\
\text { Janeiro, Brazil) }\end{array}$ & $\begin{array}{l}\text { Production of } \mathrm{CaCO}_{3} \text { in growth } \\
\text { medium }\end{array}$ & [47] \\
\hline
\end{tabular}

Ancient marble quarry in Athens, Greece Isolated during the course of the study
SEM, ERD and FTIR analyses of treated marble from same quarry
Mortar and concrete samples (National University of

Colombia-Bogota, buildings)

Psychrobacillus psycrodurans

(IBUN: Institute of Biotechnology of the National University of Colombia. Collection of microorganisms (Bogotá, Colombia))
Biocementation tests on mortar cubes; SEM, XRD, compressive strength
DSMZ: German

Collection of

Microorganisms and

Cell Cultures GmbH

(Brunswick, Germany)

Collection of the

B. licheniformis DSMZ 8782,

B. cereus $4 \mathrm{~b}$, S. epidermidi luteus 6

Enzymology laboratory of B.P. Konstantinov

Petersburg, Nuclear

Physics Institute NRC

"Kurchatov Institute"

(Moscow, Russia)
Repairing microcracks in cement, calcium carbonate precipitation
DSMZ: German

Collection of

Sporosarcina pasteurii

Microorganisms and

Cell Cultures GmbH

(Brunswick, Germany)
3-D printing using sand; hardening tests
[51]

Histological and fluorescence staining determination of cell viability inside carbonate crystals, and pore size reduction in limestone by image analysis. and F2) and Acinetobacter (isolate B14)
Freshwater sessile bacteria

Isolated during the course of the study 
Table 1. Cont.

\begin{tabular}{cccc}
\hline Organisms & $\begin{array}{c}\text { Isolation Source/ } \\
\text { Habitat }\end{array}$ & Testing Method & Reference \\
\hline $\begin{array}{c}\text { Penicillium chrysogenum } \\
\text { CS1 (Cement Sludge) }\end{array}$ & $\begin{array}{c}\text { Isolated from Cement } \\
\text { sludge } \\
\text { Isolated during the } \\
\text { course of the study }\end{array}$ & $\begin{array}{c}\text { Cementation in sand column to form } \\
\text { sandstone; compressive strength }\end{array}$ & [53] \\
\hline Colletotrichum acutatum & $\begin{array}{c}\text { Diseased fruit crops } \\
\text { Isolated during the } \\
\text { course of the study }\end{array}$ & Inoculation on limestone; SEM, EDX, \\
XRD
\end{tabular}

Abbreviations: FTIR: Fourier transform infra-red spectroscopy; XRD: X-ray diffraction analysis; SEM: scanning electron microscopy; EDS: energy dispersive X-ray spectroscopy.

One published example is that of Micallef et al. [45], who effectively treated deteriorated limestone with biocalcifying $B$. subtilis isolated from Maltese hypogea. The treatment conferred uniform bioconsolidation to a depth of $30 \mathrm{~mm}$ and the treated stone had high resistance to salt deterioration and low water absorption, with a preserved pore network. Further work on this technology is still necessary. Research by one of the authors is currently underway on a limestone wall in Campeche, southern México (Figure 1). Bioconsolidation of the damaged limestone blocks is underway using a suspension of a locally isolated carbonatogenic bacterial strain applied by spraying. Frames have been set to study the efficiency of consolidation in several quadrants, to determine variability of the results. Efficiency is being measured by surface hardness and cohesion, using peeling tests. Preliminary measurements made two months after application revealed a slight increase of surface hardness and less flake detachment. The experimental study will be continued for up to one year and both short- and medium-term effects of the treatment will be determined under the natural climatic conditions of this region, classified as Köppen climate As (Tropical Savannah).

Many other microorganisms have been tested for their calcifying and consolidation activities, including fungi (see Table 1). An important proportion of microorganisms reported in Table 1 are well characterized isolates that are deposited in established culture collections, while a significant number of bacteria were isolated during the course of the respective studies. The latter implies they are not accessible to other research groups for reproducibility or to undertake new studies. This is important for further research and also in terms of intellectual property rights. Access to microbial strains possessing desired properties such as biocalcifying activity can be exploited by patented biotechnological processes.

Chuo [55] suggested that the most studied bacterium for MICP over the years was Sporosarcina pasteurii. Omoregie et al. [56] found that this genus was the most abundant biocalcifying organism isolated from limestone cave samples, but many other species have been isolated, both by these authors and others (for example, [57]); since microorganisms with this ability are common, it is clear that there is a wide range of species available from which to choose the most appropriate for the particular stone and environment. The stone environment is often considered oligotrophic and thus isolation strategies of lithic-dwelling microorganisms should consider the design and use of low nutrient media $[58,59]$. 


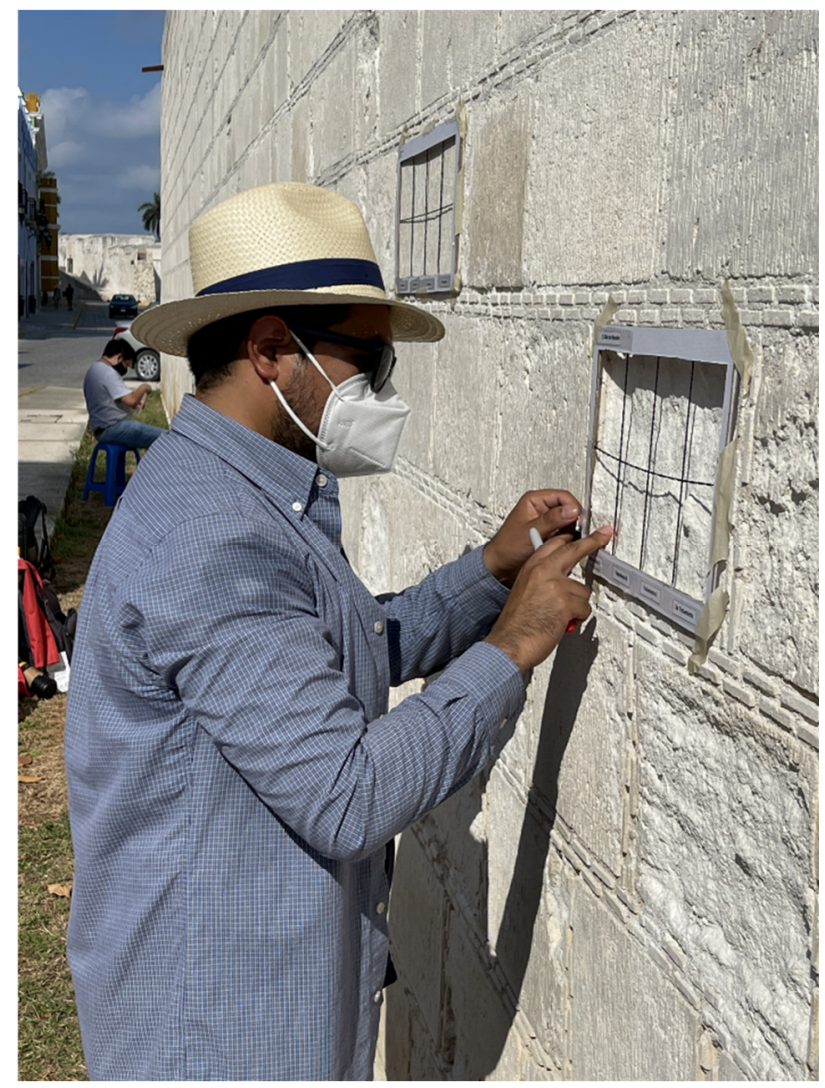

Figure 1. Limestone wall in Campeche, southern México, exhibiting a range of deterioration pathologies. Formers are being used to demarcate panels prior to treatment by spraying with carbonatogenic bacterial suspension or control solution. Replicate panels will allow statistical analysis. The aim is to increase surface hardness and reduce the detachment rate of flaking material.

Not only is the type of culture medium an important factor in the design of strategies aiming to retrieve a large number of relevant bacteria from environmental samples, but it is also necessary to use a range of isolation methods, including plating, enrichment and micromanipulation or extinction-culturing, either alone or in combination [60]. This combined approach is imperative to obtain more pure cultures of potentially dominant microorganisms derived from the stone environment, allowing a significant advance in the study of the physiology of carbonatogenic microorganisms and the environmental determinants of their activity and abundance. Pure physiologically characterized novel bacterial isolates are a prerequisite for biotechnological development across economic sectors and markets, ranging from those traditional ones already used in the food or pharmaceutical industries to emerging sectors such as cultural heritage protection.

The relatively new techniques of metagenomics and metabolomics could also play a role in selecting suitable organisms. Chimienti et al. [61], using next generation sequencing (NGS), identified the presence of known carbonatogenic bacteria like Arthrobacter in the populations colonizing the medieval church of San Leonardo di Siponto in Italy. 16S rRNA and functional gene analyses could show the carbonatogenic potential of metabolic pathways linked to the appropriate biogeochemical cycles. For metabolomics to be successfully applied to the discovery of new potentially useful organisms, however, it is necessary to better understand the biochemical processes involved in carbonatogenesis. Earlier genetic studies have, for example, used mutants impaired in $\mathrm{CaCO}_{3}$ precipitation to indicate a link between biomineralization, fatty acid metabolism, altered phospholipid membrane composition and surface properties [8,31,62-64]. Fatty acid metabolism has also been implicated by work that showed how $\mathrm{CaCO}_{3}$ precipitation in Lysinibacillus could modify membrane rigidity by upregulating branched chain fatty acid synthesis $[65,66]$. 
The prospects for the future are promising, with the combined use of improved culturing methods and metabolomics-based selection of novel carbonatogenic species. The study of their physiology and ecology should enhance the success of bioconsolidation strategies, in particular for long-term application.

Of course, other factors affect biocalcite precipitation, apart from the particular microbial species. These are cell and nutrient concentrations, source of calcium, presence of other substances, such as surfactants used as dispersants [55] and salt [24], and methods used to inoculate the bacteria onto the stone surfaces. There are several publications around this topic [31,67-69].

The alternative to application of selected carbonatogenic bacteria is to try to stimulate those already present on the stone surface. Jimenez-Lopez et al. [70] tested this approach in vitro, immersing porous limestone slabs in a nutrient medium. The positive result obtained was shown to be due to ammonification of the medium. Later, a similar approach was adopted by Jroudi et al. [71] for the consolidation of badly degraded tuff stone and lime plaster at the Mayan site of Copan (Honduras). The stone was treated with patented (sterile) M-3P nutrient solution containing amino acids and calcium. This resulted in significant changes in the indigenous bacterial community, which were detected using NGS techniques. There were increased levels of Arthrobacter, Micrococcaceae, Nocardioides, Fictibacillus, Streptomyces and Rubrobacter. In the lime plaster, Bacillus, Agrococcus, and Microbacterium were the major genera after treatment. It is notable that most of the increased components of the community after treatment were capable of calcium carbonate biomineralization. Although this may indicate that the treatment could replace application of living microorganisms, the detection of biocalcifying microorganisms does not necessarily imply that these will produce a good consolidating performance, and further testing, such as that suggested in Table 2 below, would be necessary.

Table 2. Properties of representative consolidants and methods of evaluation for stone conservation [72,73].

\begin{tabular}{|c|c|c|c|c|}
\hline $\begin{array}{c}\text { Consolidating } \\
\text { Properties }\end{array}$ & $\begin{array}{c}\text { Consolidation } \\
\text { Action }\end{array}$ & Substrate & $\begin{array}{l}\text { Consolidation } \\
\text { Treatments }\end{array}$ & $\begin{array}{c}\text { Evaluation of } \\
\text { Treatment }\end{array}$ \\
\hline Effectiveness & $\begin{array}{l}\text { Penetration } \\
\text { depth }\end{array}$ & $\begin{array}{c}\text { Marble, } \\
\text { limestone, and } \\
\text { lime-based } \\
\text { mortars }\end{array}$ & $\begin{array}{c}\text { Phosphate } \\
\text { treatment based } \\
\text { on } \\
\text { Hydroxyapatite } \\
\text { (HAP) } \\
\text { Ethyl silicate } \\
\text { (ES) }\end{array}$ & $\begin{array}{l}\text { Scanning } \\
\text { electron } \\
\text { microscopy } \\
(\text { SEM) }\end{array}$ \\
\hline Compatibility & $\begin{array}{l}\text { Morphology and } \\
\text { microstructure } \\
\text { of samples } \\
\text { resulting from } \\
\text { applied products }\end{array}$ & Marble & $\begin{array}{c}\text { Nano-solution of } \\
\text { calcium tetrahy- } \\
\text { drofurfuryloxide } \\
\text { (Ca (OTHF)2) }\end{array}$ & $\begin{array}{c}\text { Optical } \\
\text { Microscopy } \\
\text { (OM) and } \\
\text { Scanning } \\
\text { Electron } \\
\text { Microscopy } \\
\text { coupled } \\
\text { with Energy } \\
\text { Dispersive X-ray } \\
\text { spectroscopy } \\
\text { (SEM-EDX) }\end{array}$ \\
\hline Effectiveness & $\begin{array}{c}\text { Mechanical } \\
\text { properties: } \\
\text { compressive } \\
\text { strength, tensile } \\
\text { strength, } \\
\text { bending } \\
\text { strength, } \\
\text { modulus of } \\
\text { elasticity, } \\
\text { ultrasonic pulse } \\
\text { velocity, } \\
\text { abrasion loss, } \\
\text { surface } \\
\text { hardness. }\end{array}$ & $\begin{array}{c}\text { Marble, } \\
\text { limestone, and } \\
\text { lime-based } \\
\text { mortars }\end{array}$ & $\begin{array}{c}\text { HAP } \\
\text { ES }\end{array}$ & $\begin{array}{c}\text { For example, } \\
\text { tensile strength } \\
\left(\sigma_{t}\right) \text { by the } \\
\text { Brazilian } \\
\text { splitting test } \\
\text { using an } \\
\text { Amsler-Wolpert } \\
\text { loading machine }\end{array}$ \\
\hline
\end{tabular}


Table 2. Cont.

\begin{tabular}{|c|c|c|c|c|}
\hline $\begin{array}{l}\text { Consolidating } \\
\text { Properties }\end{array}$ & $\begin{array}{c}\text { Consolidation } \\
\text { Action }\end{array}$ & Substrate & $\begin{array}{c}\text { Consolidation } \\
\text { Treatments }\end{array}$ & $\begin{array}{c}\text { Evaluation of } \\
\text { Treatment }\end{array}$ \\
\hline Effectiveness & $\begin{array}{l}\text { Hardness of the } \\
\text { substrate; } \\
\text { Increase in } \\
\text { mechanical } \\
\text { strength; } \\
\text { penetration } \\
\text { depth of } \\
\text { treatment }\end{array}$ & $\begin{array}{l}\text { Limestone/lime } \\
\text { based mortar }\end{array}$ & Nanolime & $\begin{array}{c}\text { Drilling } \\
\text { Resistance } \\
\text { Measurement } \\
\text { System (DRMS) }\end{array}$ \\
\hline Compatibility & $\begin{array}{l}\text { Color changes } \\
\text { induced by the } \\
\text { treatment }\end{array}$ & $\begin{array}{l}\text { Limestone/ } \\
\text { Marble }\end{array}$ & $\begin{array}{l}\text { HAP/nano- } \\
\text { solution of } \\
\text { calcium tetrahy- } \\
\text { drofurfuryloxide } \\
\text { (Ca (OTHF) } 2)\end{array}$ & $\begin{array}{l}\text { Spectrophotometer } \\
\text { Konica Minolta } \\
\text { CM-700d to } \\
\text { measure } \\
\text { CIEL*a*b }{ }^{*} \\
\text { coordinates }\end{array}$ \\
\hline Compatibility & $\begin{array}{l}\text { Newly formed } \\
\text { phases and } \\
\text { secondary } \\
\text { by-products }\end{array}$ & $\begin{array}{c}\text { Marble, } \\
\text { limestone, and } \\
\text { lime-based } \\
\text { mortars }\end{array}$ & $\underset{\mathrm{ES}}{\mathrm{HAP}}$ & $\begin{array}{c}\text { Fourier } \\
\text { transform } \\
\text { infrared } \\
\text { spectroscopy } \\
\text { (FT-IR) }\end{array}$ \\
\hline Compatibility & $\begin{array}{l}\text { Microstructure: } \\
\text { variations in } \\
\text { open porosity } \\
\text { and pore size } \\
\text { distribution } \\
\text { after the } \\
\text { treatment }\end{array}$ & $\begin{array}{c}\text { Marble, } \\
\text { limestone, and } \\
\text { lime-based } \\
\text { mortars }\end{array}$ & $\begin{array}{c}\mathrm{HAP} \\
\mathrm{ES}\end{array}$ & $\begin{array}{l}\text { Mercury } \\
\text { intrusion } \\
\text { porosimetry } \\
(\mathrm{MIP})\end{array}$ \\
\hline Compatibility & $\begin{array}{c}\text { Thermal } \\
\text { behavior: } \\
\text { samples } \\
\text { subjected to } \\
\text { thermal cycles } \\
\text { (heating-cooling } \\
\text { cycle) }\end{array}$ & $\begin{array}{c}\text { Marble, } \\
\text { limestone, and } \\
\text { lime-based } \\
\text { mortars }\end{array}$ & $\underset{\mathrm{ES}}{\mathrm{HAP}}$ & $\begin{array}{c}\text { Use of } \\
\text { dilatometer } \\
\mathrm{L} 75 / 30 / \mathrm{C} / \mathrm{W} \\
\text { Ceramic } \\
\text { Instruments }\end{array}$ \\
\hline Durability & $\begin{array}{c}\text { Accelerated } \\
\text { weathering } \\
\text { cycles: } \\
\text { Wetting-drying, } \\
\text { freezing- } \\
\text { thawing and salt } \\
\text { crystallization } \\
\text { cycles }\end{array}$ & $\begin{array}{c}\text { Marble, } \\
\text { limestone, and } \\
\text { lime-based } \\
\text { mortars }\end{array}$ & $\begin{array}{c}\mathrm{HAP} \\
\mathrm{ES}\end{array}$ & $\begin{array}{c}\text { European EN } \\
12371 \text { and Italian } \\
\text { UNI } 11186 \text { for } \\
\text { freeze-thaw test, } \\
\text { European EN } \\
\text { 12370, RILEM } \\
\text { MS-A.1 and } \\
\text { RILEM MS-A.2 } \\
\text { for salt } \\
\text { weathering }\end{array}$ \\
\hline
\end{tabular}

\subsection{Microbial Products in Bioconsolidation Treatments}

Perito et al. [74] showed that dead, as well as live, B. cereus cells could produce carbonate crystals in liquid medium, the cell bodies acting as crystallization nuclei. It is not necessary to have whole cells for this; bacterial surfaces such as cell walls or extracellular polymeric substances (EPS) have metal binding properties that can also serve as nucleation sites [75-77]. The ability of cell walls to uptake cations such as $\mathrm{Ca}^{2+}$ was demonstrated directly for B. subtilis in much earlier work [78].

The advantages of non-cell treatments are that nutrients and appropriate growth conditions are not required and that cell components are smaller than whole cells and therefore able to penetrate further into cracks and pores (but, of course, without clogging the latter). This type of product is, however, more difficult and more expensive to prepare. A mixed inoculant, containing both EPS and living carbonatogenic cells, could give an improved performance [79].

EPS have fundamental cellular functions, including attachment to surfaces and provision of a framework for architectural growth in biofilms. They possess a varied chemistry; the composing biomolecules may include proteins, polysaccharides, lipids plus nucleic acids, lipids alone, and uronic acid. EPS may inhibit or enhance precipitation of calcium 
carbonate, depending on the functional groups which enhance precipitation by serving as initial nucleation sites, such as anionic groups like sulfate and acidic sugars [80]. Microbially influenced precipitation occurs due to the interactions of extracellular biopolymers and the geochemical environment. This is seen, for example, in the production of moonmilk speleothems, natural calcium carbonate deposits in caves, which has been associated with filamentous actinomycete activity through metabolic profiling of biomineralization pathways [81]. This, indeed, could be an interesting option for further research into bioconsolidation.

There is no consensus on the optimal conditions for biocalcification treatments, regardless of the actual method used, whether with or without cells [82]. This may be due to the fact that optimum conditions will vary depending on the type of stone, the geometry of the structure to be treated and the climate in the particular geographic location.

Conditions will certainly vary depending on the type of stone to be consolidated. Pore structure affects penetration depth and treatment performance [81]. The polymorphs produced by biocalcification are mainly calcite (rhombohedral), aragonite (needles) and vaterite (hexagonal), the final form depending on environmental conditions and bacterial strains. The most common precipitated forms are calcite and vaterite [83-85], calcite being the dominant and most thermodynamically stable $[86,87]$, although it has been suggested that microbially-induced vaterite achieves similar stability to calcite through the incorporation of organic molecules $[68,88]$. Hydrated phases of $\mathrm{CaCO}_{3}$ have also been reported $[89,90]$. The nanomechanical properties of the $\mathrm{CaCO}_{3}$ polymorphs could be improved by increased understanding of the biogeochemical processes involved [91].

\section{Effectiveness of the Consolidated Stone in the Environment}

It is important to know how the new material will perform in its particular environment. Various test methods have been used to evaluate consolidation (Table 2).

In comparison to synthetic consolidants, such as those shown in Table 2, few studies have characterized the performance of bioconsolidation methods; this is an avenue of research that could allow the development of novel approaches and strategies integrating microbiological agents or their metabolites. Novel consolidants need not only to be assessed in terms of the properties shown in Table 2, but also in their response to any microbial insults from the immediate environment.

It is imperative that the effects of the environment on the new consolidant are considered, in order to assess consolidating integrity and durability. This deserves particular attention in the future, necessitating lengthy commitment to such long-term studies.

\section{Biodeterioration Testing and Colonization of Biocalcite}

There have been few studies on the colonization of the newly produced material by environmental microorganisms, although a recent article reviews the methodologies employed to assess the durability of cultural heritage stone surfaces in response to microbial colonization [92]. Recolonization after the use of non-biological consolidants on marble, sandstone and plaster in the archeological site of Fiesole, Italy, was shown to depend mainly on the bioreceptivity of the substrate and the climatic conditions [93]. A relatively recent paper suggests that the bioconsolidation treatment based on stimulation of indigenous calcifying microorganisms does not significantly alter the stone microbiota in the long term [94]. The authors showed, using DGGE monitoring of the stone-autochthonous microbiota before and at 5, 12 and 30 months after bioconsolidation with autochthonous bacteria, that the Actinobacteria that were initially completely dominant decreased to $44.2 \%$ after 5 months. After 12 months, Cyanobacteria (22.1\%) appeared and remained dominant until thirty months. Thereafter, the population consisted of Actinobacteria $(42.2 \%)$ and Cyanobacteria (57.8\%). For the fungi, the Ascomycota phylum was dominant before treatment $(100 \%)$, Basidiomycota (6.38\%) appeared after five months, but disappeared after 12 months. After 30 months the fungal population started to stabilize and Ascomycota again dominated (83.33\%). Green algae (Chlorophyta, Viridiplantae) were rare colonizers of the new material. 
The results of this study indicated that final changes to the initial microbial populations were relatively small.

For many years, the only tests carried out on bioconsolidated stone were physical and chemical examinations, which gave information about the strength and chemical structure of the new material. There was no definitive knowledge about the ability of biocalcite to withstand the biological attacks to which it would be subjected in the environment. Indeed, Jroundi et al. [72] state that "It is unknown whether such a treatment is effective and does not produce any deleterious side effects under extreme hot and humid environmental conditions typical for the Maya area where ... the potential for microbial biodeterioration is very high". In 2015, however, Shirakawa et al. [95] subjected fiber cement panels, treated in various ways to produce a surface layer of biocalcite, to biodeterioration testing in the hot and humid climate of Sao Paulo, Brazil. They found that the calcite formed by treatment with living Bacillus sphaericus LMG 22257 plus urea plus B4 medium was the most resistant to the aesthetic biodeterioration that occurred within the 22 months of exposure. This resistance was correlated with lower water absorption and porosity, together with surface hydrophilicity, all linked to the smaller size of the biocalcite crystals. There was no apparent degradation of the crystals within the timescale of the test. Though promising, longer term experiments, often spanning several years, are necessary to truly know the extent of resistance of biocalcite to microbial attack under various environmental conditions.

\section{Other Microbial Applications in Stone Conservation}

Novel bioactive molecules based on microbial cells and products have also been used in biocleaning and protection of surfaces from microbial colonization, as discussed in the following sections. These biological techniques can be less invasive, and thus more acceptable, procedures than the traditional ones that use chemical treatments.

\section{Biocleaning}

Cleaning is one of the most important steps in the restoration process and normally comes before any other. When the building has special features, such as mural paintings, careful successive steps are necessary to remove the deposited polluting layers without affecting the original surface. The chemical and physical procedures traditionally used may have adverse effects on both the materials and the health of the restorer [96]. The recently introduced biological cleaning techniques that have been used on cultural heritage buildings in Italy, Spain and Greece, for example [97], avoid these problems. They may involve living bacterial cells or their hydrolytic enzymes. Both inorganic and organic materials can be removed gently from surfaces using these microbial products at temperatures that do not affect the underlying material.

\subsection{Removal of Inorganic Materials—Black Crusts, Nitrate Crusts}

Although some black crusts may be layers of dark pigmented cyanobacteria [3], those most commonly recognized on historic stone buildings are composed of gypsum (calcium sulphate dihydrate) and dark particulates from air pollution [98]. Traditionally, these are removed chemically with an ammonium carbonate-EDTA mixture, which may damage the underlying stone if not carefully applied. In 1992, Gauri et al. [99] reported a method for removing these layers from marble using a culture of Desulfovibrio desulfuricans, an anaerobic sulfate-reducing species better known for its ability to produce microbiallyinfluenced corrosion of steel structures [100], and references therein). After various efforts to improve the treatment (e.g., [101,102]), it was shown to be effective in removal of the crusts and preservation of the noble patina beneath them and has now been applied successfully to various monuments (e.g., [103,104]). Care must be taken, however, with the duration of the treatment. Ranalli et al. [105] used sulfate-reducing bacteria to remove sulfate crusts and found that prolonged contact between the bacteria and the stone resulted in damaging sulfide precipitation. 
Nitrate crusts are one of the types of stone efflorescences which are often considered to be of particular importance in deterioration of indoor artworks, such as mural paintings. Ranalli et al. [106] were among the first to suggest the use of nitrate reducing bacteria (a strain of Pseudomonas stutzeri in this case) to remove nitrate salts from stone. There have now been several successful cases of biocleaning of nitrates from stone; the wall paintings in the central vault of Santo Juanes church in Valentia, Spain, and the external wall of Matera cathedral are examples [107]. The latter building was treated with a novel carrier system (Carbogel) containing Pseudomonas pseudoalcaligenes that was covered with a PET film. Another novel application system was used on the mural paintings in the Santo Juanes church in Valentia [108]; Pseudomonas stutzeri DSMZ 5190 in a Japanese paper and agar layer was heated with infrared to a suitable temperature for optimum bacterial activity. Recently, Romano et al. [109] suggested that extremophilic bacteria might be good candidates for biological removal of efflorescences. Extremophiles live under extreme conditions, very high or very low temperatures, $\mathrm{pH}$ values and pressures, or in the presence of normally toxic agents such as irradiation and heavy metals. Often, they belong to the Archaea domain, but they can also be members of the Bacteria or the Eukarya (fungi or algae). The unusual conditions required for their growth means that their application as biocleaning agents should be safe, with no undesirable future effects on the environment or adverse effects on current lifeforms (including humans). This could make them more acceptable for use by conservators and restorers. Romano et al. [109] screened various extremophiles from the culture collection held by CNR, Italy, and selected an aerobic bacterium, Halomonas campaniensis $5 \mathrm{AGT}$, as a potential remediation treatment for nitrate crusts. The bacterium lives at high $\mathrm{pH}$ values and is non-pathogenic.

Mixed salt crusts also occur and these have been removed by combined biological and chemical treatments ([110], and references therein). These crusts may contain not only sulfates and nitrates, but also carbonates, apatite and protein, hence posing a challenge to traditional techniques that could be overcome by these innovative methods.

\subsection{Removal of Organic Materials}

Heterotrophic microorganisms (those that utilize organic substrates) are very versatile, producing a wide range of enzymes that can break down many organic materials. Treatment with enzymes such as proteases and collagenases is already used by restorers to remove organic residues from paintings, for example, without affecting the base material [111] Although microorganisms can be the source of such specific enzymes, it can be seen that the whole cells, containing a mixture of degrading enzymes, might be a more effective treatment in some cases, as well as being more economical. They can also be effective for otherwise difficult materials, such as casein, egg yolk, oil, and animal fat [110]. For example, Ranalli et al. [112] used cells of the bacterium Pseudomonas stutzeri, plus a final enzyme treatment, to remove organic residues, including animal glue residues, from wall paintings. The cost of the biological cleaning was much lower than that of conventional methods. More recently, the same group produced a new, improved, system, with an innovative carrier for $P$. stutzeri cells, for cleaning historic wall paintings [113]. Surface contamination of culturally important buildings by traffic fumes may also be susceptible to removal by microbial cells and their enzymes [114].

Rather than using whole bacterial cells, specific degrading enzymes can be isolated from them and used where the polluting material(s) is known. The addition of these enzymes to traditional cleaning methods can also enhance the results. Jeszeová et al. [115] successfully used a mixed enzyme preparation from the bacterium Exiguobacterium undae, containing proteases, peptidases, nucleases, peptide ABC transporter substrate-binding proteins and a phosphatase, to remove animal glue from 3 different types of substrate, glass, stone and wood from a range of trees species (Quercus sp., Fagus sylvatica, and Picea abies).

Microorganisms may be used to remove graffiti paint from heritage buildings. The modified alkyd binders and other organic polymers in the paints [116] are susceptible to some polymerases and lipases in microbial cells [116]. Sanmartin et al. [117] isolated a 
number of paint degrading strains from a wide variety of environmental sources. The most promising bacteria belonged to the genera Arthrobacter, Bacillus, Gordonia, Microbacterium, Pantoea and Pseudomonas, while fungi of the genus Alternaria also proved interesting. In 2019 , the same group tested the system on stone surfaces, using spray-painted granite and concrete coupons as the test surfaces [118]. The bacteria were grown prior to use in a culture medium enriched with powdered graffiti, to encourage the adaptation of the cells to the target paint. Macroscopic and microscopic examination, together with color and infra-red evaluations, indicated the success of the treatment. Germinario et al. [119,120] examined the effectiveness of lipase enzymes extracted from various bacteria and fungi for removing blue, green, red and black felt tip marker acrylic ink from unglazed ceramic substrates. An oil-in-water emulsion alone could remove the ink, but the addition of lipase increased the efficiency. The more gentle treatment with cells or enzymes, rather than more abrasive chemical removal, is an obvious advantage for use on culturally important monuments.

Microorganisms have also been suggested for removing biofilms, which contain high levels of protein, from historic buildings [121]. Biofilms are produced by microorganisms attaching to and thriving on the stone surface, and contain, besides the cells themselves, their metabolic products, especially EPS, and compounds that may be released by their lysis, such as proteins, lipids and nucleic acids [122]. In their mildest form, biofilms simply disfigure the surface, presenting a discolo red or dirty appearance; nevertheless, this requires treatment and, if possible prevention.

Valentini et al. [123] used the fungal enzyme glucose oxidase to clean the disfiguring patina from the surface of travertine and peperino stone from the Villa Torlonia in Rome. The hydrogen peroxide formed by the enzyme action was able to remove the thin biofilms, containing algae, cyanobacteria and heterotrophic bacteria, without etching the underlying substratum. The biocleaning method was especially recommended for travertine, whose somewhat lower porosity made it more resistant to peroxide etching. This biocleaning method was shown to be more efficient than the more traditional treatments using saturated $\left(\mathrm{NH}_{4}\right)_{2} \mathrm{CO}_{3}$ solution and EDTA in buffer and use of lipase enzyme.

Microbial cells have also been suggested as a control measure against biofilm formation. This relies on the fact that certain species can inhibit the growth of others, either by simple growth competition or by the production of antibiotic-like substances or other antagonistic metabolites $[112,124,125]$. This "biological control" is already used successfully in agriculture against plant pathogens (for example, [126,127]). However, the organisms that cause plant diseases are specific pathogens that can be inhibited by other (specific) organisms; cells growing in a biofilm on a stone surface will, unless the circumstances are unusual, consist of several species and genera. It has been suggested that antimicrobial substances produced by members of the genus Bacillus could be of interest in protecting stone surfaces from colonization ([110], and references therein), since this bacterial genus can produce a range of antibiotic substances affecting many types of bacteria; however, much work will be necessary before this becomes a truly viable option.

\section{Conclusions}

The great advantage of biorestoration based on microbial cells or their products, compared with traditional chemical, physical and mechanical methods, is that biological treatments are not destructive of the underlying substrate, simply removing unwanted overlying materials, in the case of biocleaning, or producing new stone, in the case of biocalcification. Biologically-based restoration also has the advantage of being recognized and appreciated by the community of restorers which are often reluctant to use synthetic, man-made materials. This is partially explained by the fact that ancient conservation practices are based on the use of biological materials as consolidants. Analogous behavior has been observed among other communities such as agriculture producers who are often keen to test biological-based methods in control of pests, but reluctant to use synthetic pesticides. The current COVID-19 pandemic has spurred interest in several sectors towards an increased use of green technologies. 
Cultural heritage microbiology has relied heavily on fundamental studies at laboratory scale that do not reflect conditions that occur in historic monuments, where processes operate at the monument or archaeological site level, which encompasses a heterogeneous and complex set of conditions that hamper the assessment of microbially-based approaches for conservation. There needs to be convergence of cultural heritage with civil engineering, microbiology and biotechnology to encompass a longer timeframe and greater spatial scale that includes the building/archaeological site levels. Indeed, the best approach to stone conservation is an interdisciplinary one combining engineering, art conservation and biological sciences, including microbiology, biotechnology and environmental sciences [128]. Each discipline brings its own scientific and methodological culture to develop a holistic approach.

Biotechnology has emerged as a field perceived to be a crucial component in the knowledge economy, with potential in many fields, including conservation. Using novel microbial strategies need not only consider technical aspects of performance but also safety for human use, economics and skills. Transdisciplinary approaches are key to advance science and technology in cultural heritage conservation, but they can be challenging given the gaps in knowledge. Few restorers are trained in microbiology and biotechnology skills, but also few biotechnologists are trained in social disciplines such as anthropology and conservation science. For restorers, microbiology and biotechnology skills are key for isolation and assessment of performance of novel biocalcifying organisms and the optimization of culture conditions to cost-effectively produce microbial metabolites such as EPS. EPS with the correct chemistry, which is heavily controlled by cultivation conditions, is fundamental to control and further optimize the bioprecipitation processes, offering EPS and potentially other biopolymers as tools for biotechnological applications. If correctly chosen, biological methods are completely safe, not relying on toxic or potentially poisonous solvents. In addition, it has been shown that these methods can be more economical than chemical treatments. However, as with other biotechnologies, biotechnology for cultural heritage conservation needs to further develop its methods, confirm their reproducibility and show its economic benefits. Process innovation which relies exclusively on improving environmental performance (for environmentally-conscious conservators) does not give enough incentives, in particular for the private sector. Thus, a promising cost-benefit analysis at the economic, environmental and human health levels are necessary before a phase of consolidation and progressive acceptance by the concerned communities, including conservators, governmental agencies and the private sector, are recognized.

Author Contributions: B.O.O.-M. and C.C.G. contributed equally to this paper. Both authors have read and agreed to the published version of the manuscript.

Funding: Benjamín Otto Ortega Morales is grateful for grant CONACYT CB-2015-01 257449 “Influencia de tratamientos con nano y biomateriales en la colonización microbiana de roca monumental".

Institutional Review Board Statement: Not applicable.

Informed Consent Statement: Not applicable.

Data Availability Statement: Not applicable.

Acknowledgments: The authors are grateful to Juan Enrique Pereañez-Sacarías for photo file for Figure 1.

Conflicts of Interest: The authors declare no conflict of interest associated with this article.

\section{References}

1. Scheerer, S.; Ortega-Morales, O.; Gaylarde, C. Microbial deterioration of stone monuments-An updated overview. Adv. Appl. Microbiol. 2009, 66, 97-139.

2. Schabereiter-Gurtner, C.; Piñar, G.; Vybiral, D.; Lubitz, W.; Rölleke, S. Rubrobacter-related bacteria associated with rosy discolouration of masonry and lime wall paintings. Arch. Microbiol. 2001, 176, 347-354. [CrossRef] [PubMed]

3. Gaylarde, C.C.; Ortega-Morales, B.O.; Bartolo-Pérez, P. Biogenic black crusts on buildings in unpolluted environments. Curr. Microbiol. 2007, 54, 162-166. [CrossRef] 
4. Gómez-Cornelio, S.; Mendoza-Vega, J.; Gaylarde, C.C.; Reyes-Estebanez, M.; Morón-Ríos, A.; De la Rosa, S.D.C.; Ortega-Morales, B.O. Succession of fungi colonizing porous and compact limestone exposed to subtropical environments. Fungal Biol. 2012, 116, 1064-1072. [CrossRef]

5. Ortega-Morales, B.O.; Gaylarde, C.; Anaya-Hernández, A.; Chan-Bacab, M.J.; De la Rosa-García, S.C.; Arano-Recio, D.; Montero, M.J. Orientation affects Trentepohlia-dominated biofilms on Mayan monuments of the Rio Bec style. Int. Biodeterior. Biodegrad. 2013, 84, 351-356. [CrossRef]

6. Basu, S.; Orr, S.A.; Aktas, Y.D. A geological perspective on climate change and building stone deterioration in London: Implications for urban stone-built heritage research and management. Atmosphere 2020, 11, 788. [CrossRef]

7. Palla, F. Blue-Biotechnology and Biocleaning of Historic-Artistic Artifacts. Conserv. Sci. Cult. Herit. 2016, 16, 185-196.

8. Ziegenbalg, G.; Brummer, K.; Pianski, J. Nano-Lime-A new material for the consolidation and conservation of historic mortars. In Proceedings of the 2nd Historic Mortars Conference HMC10 and RILEM TC 203-RHM Final Workshop, Prague, Czech Republic, 22-24 September 2010.

9. Zárraga, R.; Cervantes, J.; Salazar-Hernandez, C.; Wheeler, G. Effect of the addition of hydroxyl-terminated polydimethylsiloxane to TEOS-based stone consolidants. J. Cult. Herit. 2010, 11, 138-144. [CrossRef]

10. Favaro, M.; Ossola, F.; Toamsin, P.; Vigato, P.A.; Rossetto, G.; El Habra, N.; Casarin, M. A novel approach to compatible and durable consolidation of limestone. In Proceedings of the 11th International Congress on Deterioration and Conservation of Stone, Torun, Poland, 15-20 September 2008; pp. 865-872.

11. Jang, J.J.; Matero, F.G. Performance evaluation of commercial nanolime as a consolidant for friable lime-based plaster. J. Am. Inst. Conserv. 2018, 57, 95-111. [CrossRef]

12. Pozo-Antonio, J.S.; Otero, J.; Alonso, P.; Mas i Baeberà, X. Nanolime- and nanosilica-based consolidants applied on heated granite and limestone: Effectiveness and durability. Constr. Build. Mater. 2019, 201, 852-870. [CrossRef]

13. Tortora, L.; Di Carlo, G.; Mosquera, M.J.; Ingo, G.M. Nanoscience and nanomaterials for the knowledge and conservation of cultural heritage. Front. Mater. 2020, 7, 372. [CrossRef]

14. Becerra, J.; Zaderenko, A.P.; Ortiz, R.; Karapanagiotis, I.; Ortiz, P. Comparison of the performance of a novel nanolime doped with ZnO quantum dots with common consolidants for historical carbonate stone buildings. Appl. Clay Sci. 2020, 195, 105732. [CrossRef]

15. Price, C.A.; Doehne, E. Stone Conservation: An Overview of Current Research, 2nd ed.; Getty Conservation Institute: Los Angeles, CA, USA, 2010; pp. 1-175.

16. Delgado-Rodrigues, J. Stone consolidation: Research and practice. In Proceedings of the International Symposium on Works of Art and Conservation Science Today, Thessaloniki, Greece, 26-28 November 2010; pp. 1-8.

17. Caneva, G.; Nugari, M. Evaluation of Escobilla's mucilago treatments in the archaeological sites of Joya de Ceren (El Salvador). Biodeterior. Biodegrad. Lat. Am. 2005, 5, 59-64.

18. Kita, Y. The functions of vegetable mucilage in lime and earth mortars-A review. In Proceedings of the HMC2013-3rd Historic Mortars Conference, Glasgow, Scotland, UK, 11-14 September 2013; pp. 1-6.

19. Wheeler, G. Alkoxysilanes and the Consolidation of Stone; The Getty Conservation Institute: Los Angeles, CA, USA, 2005; pp. 55-64.

20. Negri, A.; Nervo, M.; Di Marcello, S.; Castelli, D. Consolidation and Adhesion of Pictorial Layers on a Stone Substrate. The Study Case of the Virgin with the Child from Palazzo Madama, in Turin. Coatings 2021, 11, 624. [CrossRef]

21. Alisi, C.; Bacchetta, L.; Bojorquez, E.; Falconieri, M.; Gagliardi, S.; Insaurralde, M.; Tatì, A. Mucilages from Different Plant Species Affect the Characteristics of Bio-Mortars for Restoration. Coatings 2021, 11, 75. [CrossRef]

22. Fierascu, R.C.; Doni, M.; Fierascu, I. Selected aspects regarding the restoration/conservation of traditional wood and masonry building materials: A short overview of the last decade findings. Appl. Sci. 2020, 10, 1164. [CrossRef]

23. Guihéneuf, S.; Rangeard, D.; Perrot, A.; Cusin, T.; Collet, F.; Prétot, S. Effect of bio-stabilizers on capillary absorption and water vapour transfer into raw earth. Mater. Struct. 2020, 53, 1-18. [CrossRef]

24. Jroundi, F.; Schiro, M.; Ruiz-Agudo, E.; Elert, K.; Martín-Sánchez, I.; González-Muñoz, M.; Rodriguez-Navarro, C. Protection and consolidation of stone heritage by self-inoculation with indigenous carbonatogenic bacterial communities. Nat. Commun. 2017, 8, 279. [CrossRef]

25. Sondi, I.; Juraěić, M. Whiting events and the formation of aragonite in Mediterranean karstic marine lakes: New evidence on its biologically induced inorganic origin. Sedimentology 2010, 57, 85-95. [CrossRef]

26. Zhu, T.; Dittrich, M. Carbonate precipitation through microbial activities in natural environment, and their potential in biotechnology: A review. Front. Bioeng. Biotechnol. 2016, 4, 4. [CrossRef]

27. Dhami, N.K.; Reddy, M.S.; Mukherjee, A. Application of calcifying bacteria for remediation of stones and cultural heritages. Front. Microbiol. 2014, 5, 304. [CrossRef] [PubMed]

28. Anbu, P.; Kang, C.H.; Shin, Y.J.; So, J.S. Formations of calcium carbonate minerals by bacteria and its multiple applications. Springerplus 2016, 5, 250. [CrossRef] [PubMed]

29. Nazel, T. Bioconsolidation of stone monuments. An overview. Rest. Build. Monum. 2016, 22, 37-45. [CrossRef]

30. Castro-Alonso, M.J.; Montañez-Hernandez, L.E.; Sanchez-Muñoz, M.A. Microbially induced calcium carbonate precipitation (MICP) and its potential in bioconcrete: Microbiological and molecular concepts. Front. Mater. 2019, 6, 126. [CrossRef]

31. Marvasi, M.; Mastromei, G.; Perito, B. Bacterial calcium carbonate mineralization in situ strategies for conservation of stone artworks: From cell components to microbial community. Front. Microbiol. 2020, 11, 1386. [CrossRef] [PubMed] 
32. Jroundi, F.; Gómez-Suaga, P.; Jimenez-Lopez, C.; González-Muñoz, M.T.; Fernández-Vivas, M.A. Stone-isolated carbonatogenic bacteria as inoculants in bioconsolidation treatments for historical limestone. Sci. Total Environ. 2012, 425, 89-98. [CrossRef]

33. López-Moreno, A.; Sepúlveda-Sánchez, J.D.; Alonso-Guzmán, E.M.; Le Borgne, S. Calcium carbonate precipitation by heterotrophic bacteria isolated from biofilms formed on deteriorated ignimbrite stones: Influence of calcium on EPS production and biofilm formation by these isolates. Biofouling 2014, 30, 547-560. [CrossRef]

34. Castanier, S.; Le Métayer-Levrel, G.; Orial, G.; Loubière, J.F.; Perthuisot, J.P. Bacterial carbonatogenesis and applications to preservation and restoration of historic property. In Of Microbes and Art; Springer: Boston, MA, USA, 2000; pp. 203-218. [CrossRef]

35. Le Metayer-Levrel, G.; Castanier, S.; Orial, G.; Loubière, J.F.; Perthuisot, J.P. Applications of bacterial carbonatogenesis to the protection and regeneration of limestones in buildings and historic patrimony. Sediment. Geol. 1999, 126, 25-34. [CrossRef]

36. Andrei, A.Ş.; Păuşan, M.R.; Tămaş, T.; Har, N.; Barbu-Tudoran, L.; Leopold, N.; Banciu, H. Diversity and biomineralization potential of the epilithic bacterial communities inhabiting the oldest public stone monument of Cluj-Napoca (Transylvania, Romania). Front. Microbiol. 2017, 8, 372. [CrossRef]

37. Li, M.; Fang, C.; Kawasaki, S.; Huang, M.; Achal, V. Bio-consolidation of cracks in masonry cement mortars by Acinetobacter sp. SC4 isolated from a karst cave. Int. Biodeterior. Biodegrad. 2019, 141, 94-100. [CrossRef]

38. Meier, A.; Kastner, A.; Harries, D.; Wierzbicka-Wieczorek, M.; Majzlan, J.; Büchel, G.; Kothe, E. Calcium carbonates: Induced biomineralization with controlled macromorphology. Biogeosciences 2017, 14, 4867-4878. [CrossRef]

39. Ferral-Pérez, H.; Galicia-García, M.; Alvarado-Tenorio, B.; Izaguirre-Pompa, A.; Aguirre-Ramírez, M. Novel method to achieve crystallinity of calcite by Bacillus subtilis in coupled and non-coupled calcium-carbon sources. AMB Express 2020, 10, 174. [CrossRef]

40. Tanul, S. Biomineralization Using Synechococcus Pevalleikii and Its Applications in Building Material. Master's Thesis, Thapar University, Patialia, India, 2017.

41. Zhu, T.; Lin, Y.; Lu, X.; Dittrich, M. Assessment of cyanobacterial species for carbonate precipitation on mortar surface under different conditions. Ecol. Eng. 2018, 120, 154-163. [CrossRef]

42. Zhu, T.; Lu, X.; Dittrich, M. Calcification on mortar by live and UV-killed biofilm-forming cyanobacterial Gloeocapsa PCC. Constr. Build. Mater. 2017, 146, 43-53. [CrossRef]

43. Li, Q.; Zhang, B.; Ge, Q.; Yang, X. Calcium carbonate precipitation induced by calcifying bacteria in culture experiments: Influence of the medium on morphology and mineralogy. Int. Biodeterior. Biodegrad. 2018, 134, 83-92. [CrossRef]

44. Andreolli, M.; Lampis, S.; Bernardi, P.; Calò, S.; Vallini, G. Bacteria from black crusts on stone monuments can precipitate $\mathrm{CaCO}_{3}$ allowing the development of a new bio-consolidation protocol for ornamental stone. Int. Biodeterior. Biodegrad. 2020, 153, 105031. [CrossRef]

45. Micallef, R.; Vella, D.; Sinagra, E.; Zammit, G. Biocalcifying Bacillus subtilis cells effectively consolidate deteriorated Globigerina limestone. J. Ind. Microbiol. Biotechnol. 2016, 43, 941-952. [CrossRef]

46. Shirakawa, M.A.; Cincotto, M.A.; Atencio, D.; Gaylarde, C.C.; John, V.M. Effect of culture medium on biocalcification by Pseudomonas putida, Lysinibacillus sphaericus and Bacillus subtilis. Braz. J. Microbiol. 2011, 42, 499-507. [CrossRef] [PubMed]

47. Daskalakis, M.; Magoulas, A.; Kotoulas, G.; Catsikis, I.; Bakolas, A.; Karageorgis, A.P.; Mavridou, A.; Doulia, D.; Rigas, F. Pseudomonas, Pantoea and Cupriavidus isolates induce calcium carbonate precipitation for biorestoration of ornamental stone. J. Appl. Microbiol. 2013, 115, 409-423. [CrossRef]

48. Montaño-Salazar, S.M.; Lizarazo-Marriaga, J.; Brandão, P.F.B. Isolation and potential biocementation of calcite precipitation inducing bacteria from Colombian buildings. Curr. Microbiol. 2018, 75, 256-265. [CrossRef]

49. Golovkina, D.A.; Zhurishkina, E.V.; Ivanova, L.A.; Baranchikov, A.E.; Sokolov, A.Y.; Bobrov, K.S.; Masharsky, A.E.; Tsvigun, N.V.; Kopitsa, G.P.; Kulminskaya, A.A. Calcifying bacteria flexibility in induction of CaCO3 mineralization. Life 2020, 10, 317. [CrossRef]

50. Keskin, T.; Deniz, I.; Aric, A.; Yilmazsoy, B.T.; Andic-Cakir, O.; Erdogan, A.; Altun, D.; Tokuç, A.; Demirci, B.F.; Sendemir-Urkmez, A.; et al. Development of ecological biodesign products by bacterial biocalcification. Eur. J. Eng. Nat. Sci. 2019, 3, 17-25.

51. Zamarreno, D.V.; Inkpen, R.; May, E. Carbonate crystals precipitated by freshwater bacteria and their use as a limestone consolidant. Appl. Environ. Microbiol. 2009, 75, 5981-5990. [CrossRef] [PubMed]

52. Fang, C.; Kumari, D.; Zhu, X.; Achal, V. Role of fungal-mediated mineralization in biocementation of sand and its improved compressive strength. Int. Biodeterior. Biodegrad. 2018, 133, 216-220. [CrossRef]

53. Li, T.; Hu, Y.; Zhang, B. Biomineralization induced by Colletotrichum acutatum: A potential strategy for cultural relic bioprotection. Front. Microbiol. 2018, 9, 1884. [CrossRef]

54. Pasquale, V.; Fiore, S.; Hlayem, D.; Lettino, A.; Huertas, F.J.; Chianese, E.; Dumontet, S. Biomineralization of carbonates induced by the fungi Paecilomyces inflatus and Plectosphaerella cucumerina. Int. Biodeterior. Biodegrad. 2019, 140, 57-66. [CrossRef]

55. Chuo, S.C.; Mohamed, S.F.; Mohd Setapar, S.H.; Ahmad, A.; Jawaid, M.; Wani, W.A.; Yaqoob, A.A.; Ibrahim, M.N.M. Insights into the current trends in the utilization of bacteria for microbially induced calcium carbonate precipitation. Materials 2020, 13, 4993. [CrossRef]

56. Omoregie, A.I.; Ong, D.E.L.; Nissom, P.M. Assessing ureolytic bacteria with calcifying abilities isolated from limestone caves for biocalcification. Lett. Appl. Microbiol. 2018, 68, 173-181. [CrossRef]

57. Vincent, J.; Sabot, R.; Lanneluc, I.; Refait, P.; Turcry, P.; Mahieux, P.Y.; Jeannin, M.; Sablé, S. Biomineralization of calcium carbonate by marine bacterial strains isolated from calcareous deposits. Matér. Tech. 2020, 108, 302. [CrossRef] 
58. Wainwright, M. Oligotrophic growth of fungi: Stress or natural state? In Stress Tolerance of Fungi; Jennings, D.H., Ed.; Marcel Dekker: New York, NY, USA, 1993; pp. 127-144.

59. Ortega-Morales, B.O.; Narváez-Zapata, J.; Reyes-Estebanez, M.; Quintana, P.; De la Rosa-García, S.C.; Bullen, H.; Gómez-Cornelio, S.; Chan-Bacab, M.J. Bioweathering potential of cultivable fungi associated with semi-arid surface microhabitats of Mayan buildings. Front. Microbiol. 2016, 7, 201. [CrossRef] [PubMed]

60. Fry, J. Culture-Dependent Microbiology. In Microbial Diversity and Bioprospecting; Bull, A., Ed.; ASM Press: Washington, DC, USA, 2004; pp. 80-87.

61. Chimienti, G.; Piredda, R.; Pepe, G.; van der Werf, I.D.; Sabbatini, L.; Crecchio, C.; Ricciuti, P.; D’Erchia, A.M.; Manzari, C.; Pesole, G. Profile of microbial communities on carbonate stones of the medieval church of San Leonardo di Siponto (Italy) by Illumina-based deep sequencing. Appl. Microbiol. Biotechnol. 2016, 100, 8537-8548. [CrossRef]

62. Barabesi, C.; Galizzi, A.; Mastromei, G.; Rossi, M.; Tamburini, E.; Perito, B. Bacillus subtilis gene cluster involved in calcium carbonate biomineralization. J. Bacteriol. 2007, 189, 228-235. [CrossRef] [PubMed]

63. Marvasi, M.; Casillas-Santiago, L.M.; Henríquez, T.; Casillas-Martinez, L. Involvement of etfA gene during $\mathrm{CaCO}_{3}$ precipitation in Bacillus subtilis biofilm. Geomicrobiol. J. 2016, 34, 722-728. [CrossRef]

64. Frandi, A.; Zucca, P.; Marvasi, M.; Mastromei, G.; Sanjust, E.; Perito, B. Bacillus subtilis fadB (ysiB) gene encodes an enoyl-CoA hydratase. Ann. Microbiol. 2011, 61, 371-374. [CrossRef]

65. Perito, B.; Casillas, L.; Marvasi, M. Factors affecting formation of large calcite crystals (=1 mm) in Bacillus subtilis 168 biofilm. Geomicrobiol. J. 2018, 35, 385-391. [CrossRef]

66. Lee, Y.S.; Park, W. Enhanced calcium carbonate-biofilm complex formation by alkali-generating Lysinibacillus boronitolerans YS11 and alkaliphilic Bacillus sp. AK13. AKAMB Express 2019, 9, 49. [CrossRef]

67. Shraddha, G.; Darshan, M. Microbially induced calcite precipitation through urolytic organisms-A review. Int. J. Life Sci. 2019, 7, 133-139.

68. Yu, X.; Zhan, Q.; Qian, C.; Ma, J.; Liang, Y. The optimal formulation of bio-carbonate and bio-magnesium phosphate cement to reduce ammonia emission. J. Clean. Prod. 2019, 240, 118156. [CrossRef]

69. Dhami, N.K.; Mukherjee, A.; Reddy, M.S. Micrographical, minerological and nano-mechanical characterisation of microbial carbonates from urease and carbonic anhydrase producing bacteria. Ecol. Eng. 2016, 94, 443-454. [CrossRef]

70. Jimenez-Lopez, C.; Jroundi, F.; Pascolini, C.; Rodriguez-Navarro, C.; Piñar-Lurrubia, G.; Rodriguez-Gallego, M.; González-Muñoz, M.T. Consolidation of quarry calcarenite by calcium carbonate precipitation induced by bacteria activated among the microbiota inhabiting the stone. Int. Biodeterior. Biodegrad. 2008, 62, 352-363. [CrossRef]

71. Jroundi, F.; Elert, K.; Ruiz-Agudo, E.; González-Muñoz, M.T.; Rodriguez-Navarro, C. Bacterial diversity evolution in Maya plaster and stone following a bio-conservation treatment. Front. Microbiol. 2020, 11, 599144. [CrossRef]

72. Sassoni, E.; Franzoni, E. An innovative phosphate-based consolidant for limestone. Part I: Effectiveness and compatibility in comparison with ethyl silicate. Constr. Build. Mater. 2014, 102, 918-930. [CrossRef]

73. Bonazza, A.; Vidorni, G.; Natali, I.; Ciantelli, C.; Giosuè, C.; Tittarelli, F. Durability assessment to environmental impact of nano-structured consolidants on Carrara marble by field exposure tests. Sci. Total Environ. 2017, 575, 23-32. [CrossRef] [PubMed]

74. Perito, B.; Marvasi, M.; Barabesi, C.; Mastromei, G.; Bracci, S.; Vendrell, M.; Tiano, P. A Bacillus subtilis cell fraction (BCF) inducing calcium carbonate precipitation: Biotechnological perspectives for monumental stone reinforcement. J. Cult. Herit. 2014, 15, 345-351. [CrossRef]

75. Douglas, S.; Beveridge, T.J. Mineral formation by bacteria in natural microbial communities. FEMS Microb. Ecol. 1998, 26, 79-88. [CrossRef]

76. Ercole, C.; Bozzelli, P.; Altieri, F.; Cacchio, P.; Del Gallo, M. Calcium carbonate mineralization: Involvement of extracellular polymeric materials isolated from calcifying bacteria. Microsc. Microanal. 2012, 18, 829-839. [CrossRef] [PubMed]

77. Oppenheimer-Shaanan, Y.; Sibony-Nevo, O.; Bloom-Ackermann, Z.; Suissa, R.; Steinberg, N.; Kartvelishvily, E.; Brumfeld, V.; Kolodkin-Gal, I. Spatio-temporal assembly of functional mineral scaffolds within microbial biofilms. NPJ Biofilms Microb. 2016, 2, 15031. [CrossRef] [PubMed]

78. Beveridge, T.J.; Murray, R.G. Sites of metal deposition in the cell wall of Bacillus subtilis. J. Bacteriol. 1980, 141, 876-887. [CrossRef]

79. Decho, A.W. Overview of biopolymer-induced mineralization: What goes on in biofilms? Ecol. Eng. 2010, 36, 137-144. [CrossRef]

80. Maciejewska, M.; Adam, D.; Naômé, A.; Martinet, L.; Tenconi, E.; Całusińska, M.; Delfosse, P.; Hanikenne, M.; Baurain, D.; Compère, P.; et al. Assessment of the potential role of Streptomyces in cave moonmilk formation. Front. Microbiol. 2017, 8, 1181. [CrossRef]

81. Ortega-Villamagua, E.; Gudiño-Gomezjurado, M.; Palma-Cando, A. Microbiologically induced carbonate precipitation in the restoration and conservation of cultural heritage materials. Molecules 2020, 25, 5499. [CrossRef]

82. De Muynck, W.; Leuridan, S.; Van Loo, D.; Verbeken, K.; Cnudde, V.; De Beile, N.; Verstraete, W. Influence of pore structure on the effectiveness of a biogenic carbonate surface treatment for limestone conservation. Appl. Environ. Microbiol. 2011, 77, 6808-6820. [CrossRef]

83. Rodriguez-Navarro, C.; Jimenez-Lopez, C.; Rodriguez-Navarro, A.; González-Muñoz, M.T.; Rodriguez-Gallego, M. Bacterially mediated mineralization of vaterite. Geochim. Cosmochim. Acta 2007, 71, 1197-1213. [CrossRef] 
84. Rusznyák, A.; Akob, D.M.; Nietzsche, S.; Eusterhues, K.; Totsche, K.U.; Neu, T.R.; Frosch, T.; Popp, J.; Keiner, R.; Geletneky, J.; et al. Calcite biomineralization by bacterial isolates from the recently discovered pristine karstic herrenberg cave. Appl. Environ. Microbiol. 2012, 78, 1157-1167. [CrossRef] [PubMed]

85. Dhami, N.K.; Reddy, M.S.; Mukherjee, A. Synergistic role of bacterial urease and carbonic anhydrase in carbonate mineralization. Appl. Biochem. Biotechnol. 2014, 172, 2552-2561. [CrossRef]

86. Stocks-Fischer, S.; Galinat, J.K.; Bang, S.S. Microbiological precipitation of CaCO. Soil Biol. Biochem. 1999, 31, 1563-1571. [CrossRef]

87. Okwadha, G.D.O.; Li, J. Optimum conditions for microbial carbonate precipitation. Chemosphere 2010, 81, 1143-1148. [CrossRef] [PubMed]

88. Jroundi, F.; Gonzalez-Muñoz, M.T.; Garcia-Bueno, A.; Rodriguez-Navarro, C. Consolidation of archaeological gypsum plaster by bacterial biomineralization of calcium carbonate. Acta Biomater. 2014, 10, 3844-3854. [CrossRef] [PubMed]

89. Gebauer, D.; Gunawidjaja, P.N.; Ko, J.Y.P.; Bacsik, Z.; Aziz, B.; Liu, L.; Hu, Y.; Berström, L.; Tai, C.W.; Sham, T.K.; et al. Proto-calcite and proto-vaterite in amorphous calcium carbonates. Angew. Chem. Int. Ed. 2010, 49, 8889-8891. [CrossRef]

90. Dhami, N.K.; Reddy, M.S.; Mukherjee, A. Biomineralization of calcium carbonate polymorphs by the bacterial strains isolated from calcareous sites. J. Microbiol. Biotechnol. 2013, 23, 707-714. [CrossRef]

91. Dhami, N.K.; Mukherjee, A.; Watkin, E.L.J. Microbial diversity and mineralogical-mechanical properties of calcitic cave speleothems in natural and in vitro biomineralization conditions. Front. Microbiol. 2018, 9, 40. [CrossRef]

92. Favero-Longo, S.E.; Viles, H.A. A review of the nature, role and control of lithobionts on stone cultural heritage: Weighing-up and managing biodeterioration and bioprotection. World J. Microbiol. Biotechnol. 2020, 36, 100. [CrossRef]

93. Pinna, D.; Galeotti, M.; Perito, B.; Daly, G.; Salvadori, B. In situ long-term monitoring of recolonization by fungi and lichens after innovative and traditional conservative treatments of archaeological stones in Fiesole (Italy). Int. Biodeterior. Biodegrad. 2018, 132, 49-58. [CrossRef]

94. Jroundi, F.; Gonzalez-Muñoz, M.T.; Sterflinger, K.; Piñar, G. Molecular tools for monitoring the ecological sustainability of a stone bio-consolidation treatment at the Royal Chapel, Granada. PLoS ONE 2015, 10, e0132465. [CrossRef]

95. Shirakawa, M.A.; John, V.M.; De Belie, N.; Alves, J.V.; Pinto, J.B.; Gaylarde, C.C. Susceptibility of biocalcite-modified fiber cement to biodeterioration. Int. Biodeterior. Biodegrad. 2015, 103, 215-220. [CrossRef]

96. Balloi, A.; Palla, F. Biocleaning. In Biotechnology and Conservation of Cultural Heritage; Palla, F., Barresi, G., Eds.; Springer: Cham, Switzerland, 2017.

97. Bosch-Roig, P.; Ranalli, G. The safety of biocleaning technologies for cultural heritage. Front. Microbiol. 2014, 5, 155. [CrossRef]

98. Warscheid, T.; Braams, J. Biodeterioration of stone: A review. Int. Biodeterior. Biodegrad. 2000, 46, 343-368. [CrossRef]

99. Gauri, K.L.; Parks, L.; Jaynes, J.; Atlas, R. Removal of sulfated-crust from marble using sulfate-reducing bacteria. In Proceedings of the International Conference Stone Cleaning and the Nature, Soiling and Decay Mechanisms of Stone, Edinburgh, UK, 14-16 April 1992; pp. 160-165.

100. Scarascia, G.; Lehmann, R.; Machuca, L.L.; Morris, C.; Cheng, K.Y.; Kaksonen, A.; Hong, P.Y. Effect of quorum sensing on the ability of Desulfovibrio vulgaris to form biofilms and to biocorrode carbon steel in saline conditions. Appl. Environ. Microbiol. 2020, 86, e01664-19. [CrossRef]

101. Bosch-Roig, P.; Lustrato, G.; Zanardini, E.; Ranalli, G. Biocleaning of cultural heritage stone surfaces and frescoes: Which delivery system can be the most appropriate? Ann. Microbiol. 2015, 65, 1227-1241. [CrossRef]

102. Cappitelli, F.; Zanardini, E.; Ranalli, G.; Mello, E.; Daffonchio, D.; Sorlini, C. Improved methodology for bioremoval of black crusts on historical stone artworks by use of sulfate-reducing bacteria. Appl. Environ. Microbiol. 2006, 72, 3733-3737. [CrossRef]

103. Gioventù, E.; Lorenzi, P. Bio-removal of black crust from marble surface: Comparison with traditional methodologies and application on a sculpture from the Florence's English Cemetery. Procedia Chem. 2013, 8, 123-129. [CrossRef]

104. Elhagrassy, A.F.; Hakeem, A. Comparative study of biological cleaning and laser techniques for conservation of weathered stone in Failaka Island, Kuwait. Sci. Cult. 2018, 4, 43-50.

105. Ranalli, G.; Matteini, M.; Tosini, I.; Zanardini, E.; Sorlini, C. Bioremediation of cultural heritage: Removal of sulphates, nitrates and organic substances. In Of Microbes and Art; Springer: Boston, MA, USA, 2000; pp. 231-245. [CrossRef]

106. Ranalli, G.; Chiavarini, M.; Guidetti, V.; Marsala, F.; Matteini, M.; Zanardini, E.; Sorlini, C. The use of microorganisms for the removal of nitrates and organic substances on artistic stoneworks. Int. Biodeterior. Biodegrad. 1996, 40, 255-261. [CrossRef]

107. Alfano, G.; Lustrato, G.; Belli, C.; Zanardini, E.; Cappitelli, F.; Mello, E.; Sorlini, C.; Ranalli, G. The bioremoval of nitrate and sulfate alterations on artistic stonework: The case-study of Matera Cathedral after six years from the treatment. Int. Biodeterior. Biodegrad. 2011, 65, 1004-1011. [CrossRef]

108. Roig, P.B.; Ros, J.L.R.; Montes Estellés, R. Biocleaning of nitrate alterations on wall paintings by Pseudomonas stutzeri. Int. Biodeterior. Biodegrad. 2013, 84, 266-274. [CrossRef]

109. Romano, I.; Abbate, M.; Poli, A.; D'Orazio, L. Bio-cleaning of nitrate salt efflorescence on stone samples using extremophilic bacteria. Sci. Rep. 2019, 9, 1668. [CrossRef]

110. Soffritti, I.; D'Accolti, M.; Lanzoni, L.; Volta, A.; Bisi, M.; Mazzacane, S.; Caselli, E. The potential use of microorganisms as restorative agents: An update. Sustainability 2019, 11, 3853. [CrossRef]

111. Mazzuca, C.; Poggi, G.; Bonelli, N.; Micheli, L.; Baglioni, P.; Palleschi, A. Innovative chemical gels meet enzymes: A smart combination for cleaning paper artworks. J. Colloid Interface Sci. 2017, 502, 153-164. [CrossRef] 
112. Ranalli, G.; Alfano, G.; Belli, C.; Lustrato, G.; Colombini, M.P.; Bonaduce, I.; Zanardini, E.; Abbrucato, P.; Cappitelli, F.; Sorlini, C. Biotechnology applied to cultural heritage: Biorestoration of frescoes using viable bacterial cells and enzymes. J. Appl. Microbiol. 2005, 98, 73-83. [CrossRef]

113. Ranalli, G.; Zanardini, E.; Rampazzi, L.; Corti, C.; Andreotti, A.; Colombini, P.; Bosch-Roig, P.; Lustrato, G.; Giantomassi, C.; Zari, D.; et al. Onsite advanced biocleaning system on historical wall paintings using new agar-gauze bacteria gel. J. Appl. Microbiol. 2019, 126, 1785-1796. [CrossRef]

114. Kohli, R. Chapter 15-Application of microbial cleaning technology for removal of surface contamination. Appl. Clean. Tech. 2019, 11, 591-617.

115. Jeszeová, L.; Bauerová-Hlinková, V.; Baráth, P.; Puškárová, A.; Bučková, M.; Kraková, L.; Pangallo, D. Biochemical and proteomic characterization of the extracellular enzymatic preparate of Exiguobacterium undae, suitable for efficient animal glue removal. Appl. Microbiol. Biotechnol. 2018, 102, 6525-6536. [CrossRef]

116. Bosch-Roig, P.; Pozo-Antonio, J.S.; Sanmartín, P. Identification of the best-performing novel microbial strains from naturally-aged graffiti for biocleaning research. Int. Biodeterior. Biodegrad. 2021, 159, 105206. [CrossRef]

117. Sanmartín, P.; DeAraujo, A.; Vasanthakumar, A.; Mitchell, R. Feasibility study involving the search for natural strains of microorganisms capable of degrading graffiti from heritage materials. Int. Biodeterior. Biodegrad. 2015, 103, 186-190. [CrossRef]

118. Sanmartín, P.; Bosch-Roig, P. Biocleaning to remove graffiti: A real possibility? advances towards a complete protocol of action. Coatings 2019, 9, 104. [CrossRef]

119. Germinario, G.; van der Werf, I.D.; Palazzo, G.; Regidor Ros, J.L.; Montes-Estelles, R.M.; Sabbatini, L. Bioremoval of marker pen inks by exploiting lipase hydrolysis. Prog. Org. Coat. 2017, 110, 162-171. [CrossRef]

120. Germinario, G.; Garrappa, S.; D’Ambrosio, V.; van der Werf, I.D.; Sabbatini, L. Chemical composition of felt-tip pen inks. Anal. Bioanal. Chem. 2018, 410, 1079-1094. [CrossRef]

121. Silva, M.; Rosado, T.; Teixeira, D.; Candeias, A.; Caldeira, A.T. Green mitigation strategy for cultural heritage: Bacterial potential for biocide production. Environ. Sci. Pollut. Res. 2017, 24, 4871-4881. [CrossRef]

122. Karygianni, L.; Ren, Z.; Koo, H.; Thurnheer, T. Biofilm matrixome: Extracellular components in structured microbial communities. Trends Microbiol. 2020, 28, 668-681. [CrossRef]

123. Valentini, F.; Diamanti, A.; Palleschi, G. New bio-cleaning strategies on porous building materials affected by biodeterioration event. Appl. Surf. Sci. 2010, 256, 6550-6563. [CrossRef]

124. Masi, M.; Petraretti, M.; De Natale, A.; Pollio, A.; Evidente, A. Fungal metabolites with antagonistic activity against fungi of lithic substrata. Biomolecules 2021, 11, 295. [CrossRef] [PubMed]

125. Marin, E.; Vaccaro, C.; Leis, M. Biotechnology applied to historic stoneworks conservation: Testing the potential harmfulness of two biological biocides. Int. J. Conserv. Sci. 2016, 7, 227-238.

126. Huang, R.; Li, G.; Zhang, J.; Yang, L.; Che, H.J.; Jiang, D.H.; Huang, H.C. Control of postharvest Botrytis fruit rot of strawberry by volatile organic compounds of Candida intermedia. Phytopathology 2011, 101, 859-869. [CrossRef] [PubMed]

127. Lopes, M.R.; Klein, M.N.; Ferraz, L.P.; da Silva, A.C.; Kupper, K.C. Saccharomyces cerevisiae: A novel and efficient biological control agent for Colletotrichum acutatum during pre-harvest. Microbiol. Res. 2015, 175, 93-99. [CrossRef] [PubMed]

128. Pope, G.; Meierding, T.; Paradise, T. Geomorphology's role in the study of weathering of cultural stone. Geomorphology 2002, 47, 211-225. [CrossRef] 